\title{
What 'Intangible' May Encompass in The Egyptian Cultural Heritage Context? Legal Provisions, Sustainable Measures and Future Directions
}

\author{
Nevine Nizar Zakaria
}

\begin{abstract}
Over the past decades, the notion of cultural heritage has been extended to incorporate the non-tangible forms that manifest the living entity of heritage at its both types natural and cultural. Egypt is rich with unique repositories of the Intangible Cultural Heritage (ICH) that reflect our diversity and cultural identities such as traditions, lifestyles, social practices, and oral heritage. Nevertheless, most of the national efforts tended to focus only on the promotion and preservation of the tangible heritage. This places the fate of the Egyptian intangible heritage at risk, as there are certain elements of the intangible assets that have disappeared. We need to adopt a set of management and legal measures for identifying, preserving and nurturing the ICH of Egypt with emphasis on integrating the community in the safeguarding process. Hence, the aim of this paper is to examine the recognition and potentials of the Egyptian ICH as a contributor for sustainable development. The paper reviews the existing efforts and legislative provisions of the protection of the ICH within the heritage discourse of Egypt in an attempt to explore to what extent the legal system support a future for the ICH of Egypt.
\end{abstract}

\section{Keywords}

Community Involvement, Cultural Expression, Folk Tradition, Intangible Culture Heritage (ICH), Law, legislation, UNESCO Convention

"The intangible cultural heritage or living heritage is the mainspring of our cultural diversity and its maintenance a guarantee for continuing creativity" (UNESCO's Convention of 2003 for safeguarding the Intangible Culture Heritage)

\section{Introduction}

Within the contemporary demands of the $21^{\text {st }}$ century heritage preservation, Intangible Cultural Heritage (ICH) has become the focus of international concern to safeguard it against the danger of disappearing. Although the Egyptian Constitution of 2014 paid unprecedented attention to the cultural issues, asserting the state's commitment to protect and preserve the cultural heritage of Egypt ${ }^{1}$, there is a clear absence of the 'intangible' heritage as a cultural asset among the Egyptian Heritage discourse. Egypt's ICH is still not properly recognized or even explained in policies and strategies, as most of the national efforts remain in the field of tangible heritage. This reveals the lack of recognition to the core values and standards of Egypt' ICH as a reflection of cultural diversity and human creativity.

Thus, this paper aims to examine the recognition of the ICH of Egypt as essential component for cultural diversity that can

${ }^{1}$ Egypts Constitution 2014, Constitute Project, translated by International IDEAss Constitution Net, (17 Jan 2018),2021- (articles 47, 48, 50), https:// www.constituteproject.org/constitution/Egypt_2014.pdf.. 
contribute effectively to sustainable development. It presents a review of the legal measures and existing delineation concerning the ICH of Egypt with special emphasis on the need for holistic management measures on the national level, aiming at safeguarding and promoting the ICH as a living heritage among the local communities of Egypt.

\section{ICH and the International Recognition}

The cultural heritage is not limited to the tangible assets and visible materials such as the immovable historical properties and landscapes, movable artifacts, or any of the monumental remains. It also includes the intangible manifestations of culture that is expressed in traditions, lifestyles, social practices, and oral heritage as well as anything that features people' relationship to the world. It is a part of the human activities that is transmitted from generation to another and ensures the sense of identity for humanity ${ }^{2}$.

In keeping up with the growing importance of ICH, the notion of cultural heritage expanded to accommodate more holistic approach shaped on the conceptualization and recognition of ICH as a living source for the culture identity, diversity, and creativity. In recent decades, the United Nations Educational, Scientific and Cultural Organization (UNESCO) had developed a series of instruments to enrich the culture heritage with the manifestations of the ICH, as well as increase the awareness of heritage forms throughout the world.

The first preliminary international action on the ICH was launched in 1982 to regulate new instrumental standards for preserving tradition, culture and folklore. This resulted in the 1989's Recommendation on the Protection of Traditional Culture and Folklore ${ }^{3}$. Later on, two sets of programmes were created to support the ICH in the face of increasing globalization: the Human Living Treasures System (launched in 1993) and the Proclamation of Masterpieces of Oral and Intangible Heritage of Humanity (launched in 1997) ${ }^{4}$.

In 2000, UNESCO has initiated the programme of the proclamation of Masterpieces of the Oral and Intangible Heritage of Humanity to raise the awareness of the ICH among the international community ${ }^{5}$. All the above-mentioned instruments have been culminated in the adoption of the 2003 convention for safeguarding the Intangible Culture Heritage that came into force in 2006 to ensure greater visibility and feasibility for the $\mathrm{ICH}^{6}$.

Due to the shared concerns in the preservation of cultural heritage, museums have been called upon to support and promote the ICH among its museological practices ${ }^{7}$. In 2004, the International Council of Museums (ICOM) endorsed the 2003 convention and invited all museums to ICH's conservation and safeguarding approaches in the 21 st general Assembly of ICOM

\footnotetext{
${ }^{2}$ Barbara Kirshenblatt-Gimblett, "Intangible Heritage as Metacultural Production,” Museum International 56, no. 1-2 (2004): 52-53; Sophie Boukhari, "Beyond the monuments, a living heritage," UNESCO Sources no. 80 (1996), http://unesdoc.unesco.org/images/0010/001033/103365e.pdf. ${ }^{3}$ Kirshenblatt-Gimblett, «Intangible Heritage,» 53; UNESCO, Recommendation on the Safeguarding of Traditional Culture and Folklore, adopted by the General Conference at its twenty-fifth session (Paris,15November1989),3-8, http://unesdoc.unesco.org/images/0009/000926/092693mb.pdf.

${ }^{4}$ Mounir Bouchenaki, «The Interdependency of the Tangible and Intangible Cultural Heritage [Conference Paper],» ICOMOS 14th General Assembly Symposium: ‘ Place, Memory, Meaning: Preserving Intangible Values in Monuments and Sites, (2731- Oct 2003) Victoria Falls, Zimbabwe; 1; UNESCO, Report on the Preliminary Study on the Advisability of Regulating Internationally, through a New Standard-Setting Instrument, The Protection of Traditional Culture and Folklore (Paris, 16 May 2001), 2, http://unesdoc.unesco.org/images/0012123437/001234/e.pdf.

${ }^{5}$ Noriko Aikawa-Faure, «From the Proclamation of Masterpieces to the Convention for the Safeguarding of the Intangible Cultural Heritage,» in Intangible Heritage, ed. Laurajana Smith and Natsuko Akagawa (Routledge; Abingdon- London, 2009), 1344-.

${ }^{6}$ Aikawa-Faure, «the Proclamation of Masterpieces,» 1344-; UNESCO, Convention for the Safeguarding of the Intangible Cultural Heritage, (Paris, 17 October 2003),http://unesdoc.unesco.org/images/0013132540/001325/e.pdf.

${ }^{7}$ Richard Kurin, «Museums and Intangible Heritage: Culture Dead or Alive?,» ICOM News 4 (2004); 79-. http://icom.museum/fileadmin/user_ upload/pdf/ICOM_News/20044-/ENG/p7_20044-.pdf; Michelle L. Stefano, «Safeguarding intangible heritage: five key obstacles facing museums of the North East of England,» International Journal of Intangible Heritage, no. 04 (2009); 112123-, https://www.academia.edu/234065/Safeguarding_ Intangible_Heritage_Five_Limitations_Facing_Museums_of_North_East_England
} 
at Seoul- Korea ${ }^{8}$.

In responding to the growing recognition of the ICH, ICOM made a significant shift in the official museum definitions in 2007 to include the "Intangible Heritage" among the core functions of museum that: "acquires, conserves, researches, communicates and exhibits the tangible and intangible heritage of humanity and its environment"9. Hence, transforming the focus of the collections and objects to the living cultural heritage and its values affirms the museum' role in preserving and transmitting the ICH in dynamic ways ${ }^{10}$.

\section{The Egyptian Context of ICH}

Egyptian culture has multi-layered complexity of recorded history that spans thousands of years with rich and highly developed civilization. It produced unique repositories of creative production of oral legacy and multiple forms of artistic culture expressions. According to the 2005' UNESCO convention on the protection of the Diversity of Culture Expressions, the culture expression is defined as: "those expressions that result from the creativity of individuals, groups and societies, and that have cultural content. ${ }^{11}$ "

Significantly, the Egyptian cultural expressions does not only represent the inherited traditions that accumulated over the past, but it also reflects our contemporary livelihoods practices in both rural and urban areas in which different communities and diverse indigenous groups take part.

Despite these wealthy resources of the Egyptian ICH, the 'Intangible' as a term and concept is unfortunate among the Egyptian arena of culture heritage. Due to its nature and ever-developing status; it cannot be touched, photographed or even displayed in museums; therefore, it is continuously exposed to negligence and extinction. Furthermore, the increasing popularity of the western lifestyles left its mark on the Egyptian culture. People started neglecting their own traditions and indeed lost many features of their local culture due to the globalization effects. This is threatening the Egyptian ICH and puts it in jeopardy of disappearing.

To understand the significance of Egypt's ICH, it's important to identify its basic characteristics and principles in the Egyptian context. Due to the diverse nature of the Egyptian ICH and its unlimited cultural forms, it is too difficult to clearly list its forms or describe its elements, not to mention being beyond the scope of this document. Hence, the author prefers to follow the five basic categories or 'domains' of the UNESCO's 2003 Convention for safeguarding the ICH in which the overall forms of intangible heritage of Egypt could be recognized ${ }^{12}$ :

\section{1) Oral Traditions}

Egypt has multiple cultures and ethnic traditions that embrace many forms of traditional cultural expressions ${ }^{1}$ Language, as emphasized by UNESCO' convention, is the vehicle of the ICH, and Egypt has a number of living ones that reflect the values of social cohesion and mutual understanding.

${ }^{8}$ Kurin,"Museums and Intangible Heritage,” 7-9; ICOM. «Seoul 2004, 21 1` General Assembly of ICOM.» (Seoul, Korea, Friday 8 October 2004), Accessed February 1,2018.

http://icom.museum/the-governance/general-assembly/resolutions-adopted-by-icoms-general-assemblies-1946-to-date/seoul-2004/.

${ }^{9}$ «Development of the Museum Definition according to ICOM statutes (20071946-), ICOM, accessed February 15, 2018. http://archives.icom. museum/hist_def_eng.html.

${ }^{10}$ Jane. K. Nielsen, «Transformations in the Postmodern Museum,» Museological Review 18, University of Leicester (2014); 23.

${ }^{11}$ UNESCO, UNESCO Convention on the Protection and Promotion of the Diversity of Cultural Expressions, (Paris, 2005) Art.4 (3).

${ }^{12}$ UNESCO, Masterpieces of the Oral and Intangible Heritage of Humanity, Proclamations 2001, 2003, and 2005 (2006), 6. http://unesdoc.unesco.org/ images/0014147344/001473/E.pdf. 
Even though the principle language is standard Arabic, but there are other indigenous languages such as Nubian language that is dominant the Upper Egypt specifically Kom Ombo and Aswan. Beja language spoken by the inhabitants of the Red Sea coast and the Eastern Desert, Domari language spoken by the elder people of the Dom community in Egypt, Bedawi language spoken by the Bedouin of Egypt and Siwi Berber of the Egyptian Berbers who living in the oases of Siwa and Gara, in addition, to other languages and multiple spoken local dialects ${ }^{13}$.

One of the most popular categories in the oral traditions is the folklore and folk tradition that dates back to Egyptian modern Renaissance in the nineteenth and early twentieth centuries and form an integral part of the national culture of Egypt ${ }^{14}$. It encompasses verbal expressions, such as folk tales, poetry and riddles ${ }^{15}$.

The oldest form of popular traditions is the 'folk literature'. It dates back to the Pharaonic culture that was full of Egyptian Mythology and traditional narratives about gods, universe, and supernatural domain ${ }^{16}$. These myths transmitted first orally and later in written forms. Numerous collections of fairytales and popular legends with genies, goblins and heroic princes have been transmitted by word of mouth and became intellectual component of the culture of modern Egypt ${ }^{2}$.

Egyptian autobiographies were a common genre in ancient Egypt; they were used as praise-songs in funeral rituals that mirrored the accepted standards of the Pharaonic culture ${ }^{17}$. In contemporary Egypt, the epic poem of Al-Sirah Al- Hilaliyyah is the most famous narrated biography and it is considered the long-standing traditional story-telling in the communities of Upper and Lower Egypt ${ }^{18}$.

\section{2) Performing Arts}

Performing arts, such as dance, theatre, and music is another part of ICH. Noticeably, the oldest illustrations of dance and music date back to the Pharaonic culture ${ }^{19}$. The depiction of "wings of Isis" is one of the famous movements re-created by modern dancers through using costuming. It is the most popular folk dance of Egypt ${ }^{20}$. There are also a wide variety of ethnic expressive dances that take different styles depending on the region such as the Nubian dances, stick dance of Upper Egypt, the delta, Sinai, Siwa with different styles, not to mention the famous Al-Tannoura Egyptian Heritage Dance ${ }^{21}$.

Interestingly, one of the most important tools for preserving the identity of the Egyptian culture is the folkloric dance; it represents the authenticity of the traditional culture expressions of Egypt ${ }^{3}$. The well-known traditional stick fighting "the Tahtib" is the most popular festive dances. It is an Egyptian martial art of stick fencing originated in the Pharaonic time ${ }^{22}$. Afterwards, it is evolved into an Egyptian folk dance, namely, "Egyptian Raks Al Assaya" which is still practiced till today,

\footnotetext{
13 «Languages Spoken in Egypt, «World Atlas, accessed March 3, 2018. https://www.worldatlas.com/articles/languages-spoken-in-egypt.html; «Languages of the World: Egypt profile,» Ethnologue, accessed March 3, 2018, https://www.ethnologue.com/country/EG.

${ }^{14}$ Ahmed Morsi, «Research and Preservation projects on Intangible Heritage,» Museum International 225226-, Heritage Landscape of Egypt (UNESCO, 2005); 61,

http://unesdoc.unesco.org/images/0014140905/001409/e.pdf.

${ }^{15}$ UNESCO and WIPO, Model Provisions for National Laws on the Protection of Expressions of Folklore against Illicit Exploitation and Other Prejudicial Actions, (Paris, (1985), Section 2, 910-. http://www.wipo.int/export/sites/www/tk/en/folklore/1982-folklore-model-provisions.pdf.

${ }^{16}$ Vincent A. Tobin, «Mythological Texts,» The Oxford Encyclopedia of Ancient Egypt-OEAE II, (2002); 459464-.

${ }^{17}$ Joyce B. Harris, African and African-American Traditions in Language Arts, Portland Public Schools Geocultural Baseline Essay Series, (n.d.) 12 ff. http:// www.pps.k12.or.us/depts-c/mc-me/be-af-la.pdf

${ }^{18}$ Morsi, «Research and Preservation,» 6566-.

${ }^{19}$ Lise Manniche, Music and Musicians in Ancient Egypt, (London, 1991), $11 \mathrm{ff}$.

${ }^{20}$ Heather Emerson, «Belly Dance,» Hobby Profile: Belly Dance 1. Hobbies \& Crafts Reference Center, EBSCO host (2013); 17-. library.cityoftyler.org.

${ }^{21}$ Sahra, C. Kent, «The Different Dances of Egypt,» Journey through Egypt, Posted on January 16 ${ }^{\text {th }} 2014$ (Dance Style), http://journeythroughegypt. com/the-different-dances-of-egypt/; Wendy Buonaventura, Serpent of the Nile: Woman and Dance in the Arab World, (Northampton, 2010) 5 ff.

${ }^{22}$ Wolfgang Decker, «Sports,» The Oxford Encyclopedia of Ancient Egypt- OEAE III (2001); 312; Jonathan W. Riddle, «Ancient Egyptian Stick Fighting,» Journal of Combative Sport (2007),

http://ejmas.com/jes/2007jes/jesart_riddle_0807.html.
} 
transmitting social values and symbolic representations of skills and knowledge $\mathrm{e}^{23}$.

The richness of the popular culture of the Egyptian diversity is reflected widely in various types of folk music associated with dramatic performances. Folk songs represent the lives of the Egyptian people and their life cycle, while the occasional songs and religious praises are associated with the natural phenomena such as the fall of the rain or solar and lunar eclipse ${ }^{24}$.

\section{3) Social Practices, Rituals and Festive Events}

Egypt is wealthy with habitual activities and practices that provide structure for everyday life. Seasonal occasions, ceremonial events, rites of birth, wedding, funeral rituals, markets and cafes and much more events mirrored the pattern of the lives of Egyptians with significant repository of popular customs and social behaviors. In addition, there are the rich materials of life practices and popular traditions that manifested through the etiquette of hospitality, food and drink habits and other practices associated with economic and law activities (etc. $)^{25}$.

Different types of traditional festivals mark the collective identities of several ethnic groups. AlMawlid-traditional festival- is the most popular genre of festival events in Egypt and a significant manifestation of Egypt's ICH. It is celebrated by Muslims, Christians, and Jewish to honor their saints in many regions from the Nile Delta to Upper Egypt ${ }^{26}$. All the aforementioned practices embody a variety of culture expressions and behavioral patterns that affirm the national identity of a wide variety of Egyptian folk groups and promote inter-cultural dialogue among them. Moreover, it empowers the community with the sense of belonging and continuity to their traditions.

\section{4) Knowledge and Practices Concerning Nature and the Universe}

Interacting practices with the natural world and the immediate environment has strong influences on the Egyptian culture since ancient times. Themes as cosmologies, renewal of life, chaos, Nile, and worldview are expressed in numerous stories and traditional wisdoms ${ }^{27}$. On the other hand, healing practices and traditional medicine theories that passed down from generation to generation form an important part of everyday life and reflect the medical knowledge and traditional culture of the People of Egypt. The ways that the local communities view the universe are expressed through traditional ecological knowledge, oral tradition, and nostalgia towards places and memories. All these aspects have a strong influence on the Egyptian beliefs and transmit crucial core values of the cultural tradition and the social practices of Egypt.

\section{5) Traditional Craftsmanship}

Traditional craftsmanship is considered the most tangible manifestation of the ICH. Egypt is rich with authentic cultural products that have been handed down from generation to generation with inherited aesthetic skills and accumulated knowledge. This visible material is ranging between crafts and folk art such as pottery, carpentry, blacksmithing, etc., to popular building, and other crafts such as clothing, sewing included- embroidery, mats and carpets of various ethnic groups of Egypt ${ }^{28}$. Dimensions

\footnotetext{
${ }^{23}$ See: UNESCO Egypt, Country Nomination file no. 01189 for inscription in 2016 on the Representative List of the Intangible Cultural Heritage of Humanity, intergovernmental Committee for the Safeguarding the Intangible Cultural Heritage, eleventh session ( Addis-Ababa, Ethiopia, 2016 ),3-6. https://ich.unesco.org/en/RL/tahteeb-stick-game-01189.

24 "Folk Traditions," Egyptian Archives of Folk Life and Folk Traditions, accessed January 25, 2018. http://nfa-eg.org/En/egypt_folk_dances/egypt_ folk_Definition.aspx?SecID=7.

25 “Folk Traditions," Egyptian Archives of Folk Life and Folk Traditions, accessed January 25, 2018. http://nfa-eg.org/En/egypt_folk_dances/egypt_ folk_Definition.aspx?SecID=7.

${ }^{26}$ ESFT and UNESCO, Research Project of Safeguarding Egyptian Traditional Festivals: Collecting \& Documenting Egypt 2008,(Egypt, 2008), 68-, http://esft.info/Books/Festivals.pdf.

${ }^{27}$ Veronica Ions, Library of the World's Myths and legends: Egyptian Mythology, (New York, 1982), 2130-.

${ }^{28}$ «Folk Traditions,» Egyptian Archives of Folk Life and Folk Traditions, accessed January 25, 2018. http://nfa-eg.org/En/egypt_folk_dances/egypt_ folk_Definition.aspx?SecID=7.
} 
of Knowledge and local practices are associated with popular crafts such as agriculture, fishing, hunting, transporting, not to mention the tools and machines used in music, drama, sports, and dance among other popular practices. These crafts are unique manifestation of the living cultural context and it offers deep insights on the lives of the crafts -workers and traditions they express and sustain.

In the view of the above stated, many valuable elements of ICH are endangered, due to the lack of recognition, understanding and the adequate safeguarding means. Egypt's ICH is a living changing heritage that should therefore be preserved to prevent its loss or freezing as indicated in the UNSECO instruments "if the ICH is not nurtured it risks becoming lost forever, or frozen as a practice belonging to the past" ${ }^{29}$.

Recognizing this intangible legacy of Egypt and its values will promote knowledge, mutual respect amongst culturally diverse communities, in addition to, reconciliation and peace, which are essential elements for social cohesion. On a different note, it can contribute significantly to the economic growth of Egypt by retaining the local accumulated knowledge and generating employment opportunities for developing the local people. Thus, it can be used as an important source for attracting tourism with economic benefits. In essence, it considerably bolsters the continuity of the human creativity and retains the local knowledge through linking the past, with the present, and into the future through continuous transmission of skills and meanings that is derived from the achievements of the ancient Egyptian civilization.

\section{National Institutions and Bodies Involved in Safeguarding the Egyptian ICH}

There are a number of governmental and non-governmental bodies that address the protection and promotion of the ICH in Egypt, especially the folk culture. Despite this, Egypt lacks an institutional governmental department with legal framework and formulated policies dedicated to managing and mobilizing the ICH of Egypt from a holistic perspective. However, this section aims to identify the institutional actors and national agencies that are involved in safeguarding the Egyptian ICH.

\section{a) The Institutional Governmental Environment}

The Ministry of Culture (MoC) is the overall responsible body for maintaining and promoting the protection of the Egyptian ICH. It was founded in 1958 to define the national identity of the Egyptian nation with the purpose of protecting the cultural heritage of Egypt whether tangible or intangible ${ }^{30}$. It has different cultural institutions under its jurisdiction including the Supreme Council of Culture, Cultural Development Fund and the Supreme Council of Antiquities that has been separated in January 2011 to be the Ministry of Antiquities as the main institution leading the protection of cultural heritage defined as sites pre-dating 1883.

The first initiatives of MoC to raise the awareness of the Egyptian Folklore as integral part of the Egyptian cultural structure was the establishment of the Folklore Committee in 1956, to promote the Egyptian Folklore movement and set up the Egyptian Folklore archives ${ }^{31}$. Currently, it serves as advisory board for MoC that provides guidance for activities to protect the Egyptian folk culture.

In late 1957, the Egyptian Government established a research centre for folklore studies, but due to several circumstances, the centre failed in achieving its purpose. In 1981 the MoC established the Higher Institute for Folklore under the affiliation of the Academy of Arts for collecting, recording and studying materials of folklore and

\footnotetext{
${ }^{29}$ UNESCO, What is Intangible Cultural Heritage?, (n.d.), 6, https://ich.unesco.org/doc/src/0185 1-EN.pdf.

${ }^{30}$ Sonali Pahwa and Jessica Winegar, «Culture, State and Revolution,» Middle East Research and Information Project- MERIP 42 (263), accessed March 21, 2018. https://www.merip.org/mer/mer263/culture-state-revolution; Jessica Winegar, «Culture is the Solution: the Civilizing Mission of Egypts Culture Palaces,» Romes 43 (2), (2009); 189191-.

${ }^{31}$ Morsi, «Research and Preservation,»; 6163-.
} 
the folk traditions of $\mathrm{Egypt}^{32}$. Afterwards, it encompassed the above mentioned centre of folklore studies amongst its branches for scientific research purposes ${ }^{33}$.

In 1989, the creation of the General Cultural Organization of Culture Palaces marked a forward step in spreading awareness of folk traditions throughout Egypt by providing a wide range of cultural events and platforms to display performances of the traditional folklore and music ${ }^{34}$. Then, in 1990 the Egyptian folklore Atlas Project was launched to define the folk's elements of Egypt historically and geographically ${ }^{35}$.

In addition to the above mentioned, The Center for Documentation of Cultural and Natural Heritage (CultNat), under the affiliation of Bibliotheca Alexandrina (semi-governmental institution), is involved in some projects related to documenting the Egyptian arts and Folklore such as the heritage of Nubia and Siwa ${ }^{36}$.

Also, the Egyptian National Commission for UNESCO under the Ministry of Higher Education is providing services and supports the implementation of the convention of the Safeguarding of ICH in Egypt and facilitates extensive programmes with financial support of $\mathrm{UNESCO}^{37}$.

Others institutional actors indirectly play an active role towards the ICH of Egypt ${ }^{4}$, including the Industrial Modernization Center of the Ministry of Industry (IMC) that is engaged in some programmes related to promoting the recognition of the Egyptian traditional craftsmanship. Moreover, it incorporates the traditional crafts into its development programme to improve the national economy of the country ${ }^{38}$.

Also the National Council of Women (Governmental institution) provides financial support and socio-economic programmes for the women of Upper Egypt with the purpose of the revitalization and transmission of one of the traditional crafts called 'Art of Tally' ${ }^{39}$. It is a hand-carved motif formed by metal embroidery and geometric figures used for occasional dresses by the women of Assuit region at Upper Egypt since the nineteenth century ${ }^{40}$. Nowadays, this craft is near to extinction which poses a threat to the sustainability of the craft whilst it can be used broadly as an industry with great economic opportunities.

\section{b) Non-governmental Environment}

There are a number of civil society institutions and NGOs that are working in the field of ICH in Egypt. In researching these non-governmental institutions, two main organizations became evident. One is the Egyptian Society for Folk Traditions (ESFT) that was established in 2002 to provide a scientific and cultural consultation in the field of ICH ${ }^{41}$. It confronts the threats incurred on the traditional folk's practices by awareness-raising efforts aimed at nurturing the folk cultures against freezing and looting. The other one is the Egyptian Archives of Folk Life and Folk Traditions that

32 «Academy of Arts,» Egypt State Information Service, accessed March 15, 2018

https://web.archive.org/web/20081118175925/http://www.sis.gov.eg/En/Arts\%26Culture/AcademyofArts/07 1200000000000001.

htm.

${ }^{33}$ Morsi, "Research and Preservation," 63-64.

${ }^{34}$ Winegar, «Culture is the Solution,» 191193-.

${ }^{35}$ Morsi, «Research and Preservation,» 6364-.

36 «The Center for Documentation of Cultural and Natural Heritage (CultNat),» accessed March 5, 2018: http://www.cultnat.org/

37 «The Egyptian National Commission for Education Culture and Science,» accessed February 22, 2018.

http://www.egnatcom.org.eg/ich/en

38 "Report on Traditional Crafts for IMC of the Ministry of Industry," Egyptian Society for Folk Traditions (ESFT), accessed March 10, 2018, http://www. esft.info/en/Projects/Default?id=15.

39 «Tally: The Art of Tally,» Egyptian Society for Folk Traditions (ESFT), accessed March 10, 2018, http://esft.info/en/Projects/Default?id=10.

${ }^{40}$ Noha Abdel -Wahab, « Al-Tally ascension Journey from an Egyptian Folk Art to International Fashion Trend,» Journal of Architecture and Arts 10 (2018):5883-, https://www.aaciaegypt.com/wp-content/uploads/201804//\%E29\%80\%CAl-tally\%E29\%80\%D-ascension-journey-from-anEgyptian-folk-art-to-international-fashion-trend.pdf

${ }^{41}$ ESFT and UNESCO, Research Project, 67. 
was founded in 2008 to conduct researches and inventory's projects on national folk traditions ${ }^{42}$. Also it offers a set of theoretical and applicable training to supply scholars and agencies with appropriate data on the cultural folk traditions of Egypt.

It's worth mentioning here that, most of the institutions listed above are working independently, and they lack consistency and unified methodologies in recording, documentation, and inventory-making, etc.

\section{Egyptian Delineation and Legislative Measures towards ICH}

Till present, Egypt lacks effective legislative measures for protecting the ICH on governmental level. National Projects, programmes, and NGOs were established to compensate the absence of legal measures. This section aims to examine the current efforts and the national legislation provisions for safeguarding Egypt's ICH.

\section{- International Measures:}

Following the spirit of UNESCO's 2003 convention for the safeguarding of ICH, Egypt has joined and ratified the convention in 2005. As a result, two elements have been inscribed in the representative list of the intangible cultural heritage of Humanity; 1) the epic of Al-Sirah Al-Hilaliyya inscribed in 2008 (originally proclaimed in 2003) ${ }^{43}$; 2) The Tahteeb Stick, inscribed in 2016 - festival game related to the martial -arts practices- ${ }^{44}$.

It should be noted that these two elements have been nominated and submitted to the UNESCO programme with the great help and active support of the community, national NGOs and the practitioners in an approach to foster the sense of Egyptian identity that is rooted into these practices, in addition to contribute in the transmission of and engagement with their ICH as cultural custodians.

At present, there is one element - Traditional Hand puppetry- classified as "On going", and three other elements on the backlog nominations ${ }^{45}$ :

\section{- 2015: Egyptian traditional weaving industry (handloom silk weaving)}

- 2014: inventories of intangible culture in six areas in Egypt.

\section{- 2014: pottery}

Accordingly, there are only six elements that are considered in need of urgent safeguarding, and these are limited numbers considering the richness of Egyptian' ICH that covers all the five domains of the convention on ICH, taking into account that many of them are being heavily endangered to disappearing. Moreover, the delayed actions in inscribing them could result in their demolition.

\section{- National Measures:}

Egypt's cultural heritage has national laws and legislations committed towards the protection of Egyptian heritage or "Marvels of the Past Centuries", as described in the first decree of 1835 for the protection of Egyptian antiquities issued by the modern Egyptian state ${ }^{46}$. Several laws and by-laws have been issued constantly since the late $19^{\text {th }}$ century and throughout the $20^{\text {th }}$ century addressing the protection of the cultural heritage. A number of formulated amendments and other legislative measures

\footnotetext{
42 « The Egyptian Archives of Folk Life and Folk Traditions,», accessed February 1, 2018, http://nfa-eg.org/En/.

${ }^{43}$ UNESCO Egypt, Periodic Report on the Convention for the Safeguarding of the Intangible Cultural Heritage: Intergovernmental Committee for the Safeguarding of the Intangible Cultural Heritage- Seventh Session, Paris- Periodic Report No. 00788/Egypt, 2, https://ich.unesco.org/en/state/egyptEG?info=periodic-reporting\# pr-20122012-

${ }^{44}$ UNESCO Egypt, Country Nomination file, 113-.

${ }_{45}$ «Egypt and the 2003 Convention,» UNESCO, accessed January 12, 2018, https://ich.unesco.org/en/state/egypt-EG.

${ }^{46}$ UNESCO Egypt, Working Paper Submitted by the Egyptian Delegation to the Conference Meeting of Open Membership Team of Governmental Experts Concerning Protection from Illicit Trading in Cultural Property, (Vienna from 24 to 26 November, 2009), 2, accessed January 1, 2018, http://www.unodc. org/documents/treaties/organized_crime/Egypt.pdf.
} 
have been regulated in the 21 st century to support the legal protection of the Egyptian antiquities including Law No. 117 of 1983 that has been amended by law No. 3 of 2010 for promulgating the Antiquities protection law ${ }^{47}$.

Whilst reviewing these heritage laws, it is noticed that all the provisions of the Egyptian law that relates to the cultural heritage are focusing only on the tangible heritage with no reference to any of the intangible forms of the Egyptian civilization. The word 'intangible' is somehow lost, as the state has yet to consider any legal measures to ensure the protection of intangible materials. Remarkably, the current Egyptian constitution that was approved by popular and general referendum on January 2014 contains provisions asserting the state commitment for protecting and preserving the cultural Heritage ${ }^{48}$. By examining these provisions, three fundamental principles related to the notion of ICH were represented:

(1) The Principle of Cultural Identity which is reflected in article 47:

“The state is committed to protecting Egyptian cultural identity with its diverse Civilizational origins".

(2) The principle of Cultural Rights manifested in article 48:

"Culture is a right of every citizen that is guaranteed by the state. The state is committed to support it and provide all types of cultural materials to the different groups of people without discrimination".

(3) The principle of protecting and maintaining the material and moral civilizational and Cultural Heritage in article 50, in which the state said:

"Egypt's material and moral civilizational and cultural heritage of all types and from all of the Pharaonic, Coptic, Islamic, and modern periods are a national and human heritage that the state commits to protect and maintain. The state gives special attention to maintain the components of cultural diversity".

Even though the term "intangible' is not described within these provisions, but the 'Cultural Heritage of all types' is definitely a reference to both its facets whether tangible or intangible. Noticeably, the above listed articles illustrate basic concepts heavily related to the ICH such as the cultural identity, cultural rights, the protection of cultural heritage and maintaining the components of cultural diversity. Doubtlessly, these provisions are vital requirements for safeguarding the ICH of Egypt. It reveals the state desire to protect the sense of identities and diversity of cultures as a main component of the national cultural that contributes to shaping the Egyptian cultural structure. It also reflects the state recognition and concern to the cultural rights that is crucial to maintain the continuity of the social and cultural identity of the country.

While the state emphasizes its commitment to issues such as cultural identity and diversity, it lacks regulatory instruments or written guidelines to assist in developing actions on the ground for the protection of ICH. Most importantly, it has yet to provide any sustainable strategy for empowering the communities as cultural custodians to their diverse cultural manifestations against the on-going threats to their endangered cultural resources.

\section{- The Sustainable Development of Egypt 2030 (SDS):}

In 2014, the Egyptian government has issued a long-term strategic plan towards the future- "Egypt's Vision 2030"- to illustrate Egypt's road map that spans over the three dimensions of sustainable development, namely; economic, social and environmental dimensions. It aims to improve the quality of life of Egyptian citizens on all levels including the cultural life in alignment with the current reality. Amongst the proposed agenda for developing the cultural infrastructure is a set of activities that aimed at raising the awareness with the heritage of Egypt in both tangible and intangible forms, in particular produce documentary clips

\footnotetext{
${ }^{47}$ Supreme Council of Antiquities, Law No. 117 of 1983, as amended by Law N. 3 of 2010 (14 February, 2010), promulgating the Antiquities Protection Law (6 August 1983), 139-.

${ }^{48}$ Egypts Constitution 2014, 2021 - (articles 47, 48, 50).
} 
and movies about the traditional crafts $^{49}$.

Within the framework of the SDS vision, a set of programs have been suggested to support achieving the strategic objectives. Among these programs, two national programs are concerned with preserving the ICH of Egypt. Program (1) aims to digitize all tangible and intangible forms of heritage and make it accessible electronically to ensure sustainable protection of the Egyptian identity. Program (2) aims at protecting and developing the traditional crafts of Egypt and ensures transference of knowledge through financing and marketing stimulation ${ }^{50}$.

Obviously, The ICH of Egypt needs more extensive programs and planned efforts to achieve sustainability. Moreover, the ICH-related programs in the SDS are not covering all the categories of Egypt's ICH as they focused only on the traditional crafts, whilst there is a clear absence for the tradition bearers and practitioners as one of the most required means to ensure transmission of knowledge. The SDS also overlooked the elements of ICH in both the cultural programs and performance indicators that have been selected to measure the extent of development on the future vision.

\section{Sustainable Measures for Safeguarding the Egyptian ICH}

This section aims at provoking sustainable measures for protecting the fragile ICH of Egypt and promoting its resources as part of the 'living culture' that should be transmitted intact to future generations.

In this concern, and after reviewing the existing Egyptian delineation towards the ICH, a number of facts that are crucial for the future direction of Egypt's ICH have been revealed; first, the absence of legislative environment is one of the key challenges facing the process of safeguarding the ICH. Despite the fact that the Egyptian Constitution acknowledges some aspects of the ICH, the government has yet to formulate legal provisions for its identification, conservation, preservation and protection. In addition, the current Egyptian Heritage law or what's known as Antiquities law lack any legislative measures for protecting and promoting the ICH whether as intellectual property or as living Human Treasures.

The second is the lack of intersectoral governmental department with management structure. It's a fact that MoC provides a degree of protection for the folk traditions as a vital component of ICH of Egypt, but other aspects of the great richness of Egyptian intellectual creativity and cultural expressions are still left behind. Indeed, the ICH of Egypt is exceptionally broad and it's impossible to safeguard each element in its cultural diversities, but defining its core elements can be approached through inclusive institutional arrangements with solid administrative measures.

The third is the absence of formalized coordination with binding instruments to regulate the relation between national NGO's and non-governmental bodies that are concerned with protecting the ICH of Egypt. Their efforts should be integrated through unified methodology, visions, and directions for the sake of safeguarding Egypt's ICH. Taken in account that, most of their efforts remain only in the field of gathering and collecting various forms of Egypt' ICH while other means such as, inventorying, documentation, preservation, promotion and revitalization are still not fully undertaken.

Also, and as stated earlier, the ICH of Egypt is still not identified, or even recognized in national policies. Moreover, it is still not fully perceived by its producer, i.e. the community. The priority for national and local authorities is still the tangible heritage only. Many projects oriented towards conserving and preserving the monumental properties rather than the intangible legacy of Egypt.

Moreover, safeguarding the ICH will never be achieved without the involvement of the Community, as the local bearers and holders of knowledge, skills and practices are the actual custodians of the cultural heritage. According to the 2003's UNESCO Convention, communities, groups, in some cases individuals, play a major role in the production and maintenance of the ICH.

\footnotetext{
${ }^{49}$ Ministry of Planning, Monitoring and Administrative Reform, Sustainable Development Strategy. Egypt's Vision 2030, (Cairo 2015), accessed August 20, $2017,217,-230$,

http://www.mfa.gov.eg/SiteCollectionDocuments/SDS2030_English.pdf.

${ }^{50}$ Ministry of Planning, Sustainable Development Strategy., 228229-
} 
Thus, the most sufficient mechanism for Egypt to achieve sustainable measures for safeguarding our national ICH would be through ensuring that the bearers value their heritage and recognize its standard. Hence they will be able to perform their practices and subsequently participate in documenting their skills and knowledge for the future generations.

Also, Egypt needs to liberate from the old static perceptions of cultural heritage as physical monumental properties, and promote a broad new vision towards safeguarding the intangible forms of the remarkable legacy of the past. "Objects and places are not, in themselves, what is important about cultural heritage. They are important because of meanings and uses that people attach to them and the values they represent within a heritage community", state the International Conference on Museums and Intangible Cultural Heritage ${ }^{51}$.

In keeping up with this vision, Egypt needs to adopt a long term strategic plan based on the full participation of the community, taking into account the visions of NGOs and the non-governmental authorities towards the future directions of preserving the national ICH. In order to achieve this, the Egyptian Government needs to provide legal protection for the ICH against illicit import, loss, extinction and other impacts of globalization. It needs to provide several legislations to guarantee ICH's protection and transmission, most importantly preserve our ownership of the ICH as cultural property.

It is within this context that various codes and national acts need to be considered towards addressing the registration procedures, inventory methods and human rights provisions for the concerned communities or the cultural bearers. Also, a national ICH policy is required to support the legal provisions and the participatory community methodologies. As part of the new suggested vision, the Egyptian museums should step towards safeguarding the non-tangible forms of the materials culture and contribute in reinterpreting and communicating the ICH as a living heritage.

\section{Conclusion}

Safeguarding Egypt's ICH requires much more than creating inventories or supporting documentation. It needs developing laws and legislations to foster sustainable development. It is essential to establish administrative bodies, and reformulate cultural policy to promote awareness and dialogue among the culture leaders and institutional actors towards a forward-looking vision for recognizing the ICH of Egypt. Most importantly, promote ‘Community-based Participation’ in identifying and interpreting ICH of Egypt as living dynamic Heritage.

\footnotetext{
${ }^{51}$ Valentina L. Zingari, Rosario Perricone and Pietro Clemente (Simbdea), Position Paper: International Conference and Expert Meeting on Museums, Intangible Cultural Heritage and Participation (2728- February, 2018, Palermo), accessed April 10, 2018, 6.

https://www.ichandmuseums.eu/en/events/detail/expert-meeting-intangible-cultural-heritage-museums-and-participation.
} 


\section{Bibliography}

1- Traditional Cultural Expressions (TCEs) also known as «expressions of folklores». These are synonyms terms that used alternatively to refer to: traditional music, dance, art, designs, names, signs, performances, ceremonies, architectural forms, handicrafts and narratives. They embodied the cultural and social identities of the local communities, and their protection is part of the preservation of Cultural Heritage:

WIPO, Glossary of Key Terms related to Intellectual Property and Generic Resources, Traditional Knowledge and Traditional Cultural Expressions, in: Intergovernmental Committee on Intellectual Property and Genetic Resources, Traditional Knowledge and Folklore, Twenty - Second Session, (Geneva, July 9-13, 2012), 40-41.

http://www.wipo.int/edocs/mdocs/tk/en/wipo_grtkf_ic_22/wipo_grtkf_ic_22_inf_8.pdf

2- Egypt has rich resources of fairytales and legends that have some Arabian influences. It is also circulated the western world and inspired countless of European fairy stories such as ; Arabian Nights which known as «one thousand and one nights>, Ali -Baba and the forty thieves, Sinbad the Sailor, Aladdin and the magical lamp.

3- One of the most famous folkloric dances of Egypt is Mahmoud Reda, a troupe focused on presenting the authentic roots of the Egyptian traditional culture. See: Emerson, «Belly Dance,»; 2

4- Ministry of Youth \& Sports and Ministry of Education were amongst the governmental actors that supported the nomination file of the Tahtib game for inscription in 2016 on the representative list of intangible cultural Heritage of Humanity. Furthermore, Ministry of Youth \& Sports provided venues for the Tahtib`s representatives- bearers to maintain and spread the game among the youth, while Ministry of Education has integrated the Tahtib game amongst the sports -activities of national schools: see

UNESCO Egypt, Country Nomination File, 7.

Bibliography

Abdel-Wahab,Noha. «Al-TallyascensionJourneyfromanEgyptianFolkArttoInternationalFashionTrend,»JournalofArchitecture and Arts 10 (2018):58-83, https://www.aaciaegypt.com/wp-content/uploads/2018/04/\%E2\%80\%9CAltally\%E2\%80\%9D-ascension-journey-from-an-Egyptian-folk-art-to-international-fashion-trend.pdf

Aikawa-Faure, Noriko. «From the Proclamation of Masterpieces to the Convention for the Safeguarding of the Intangible Cultural Heritage,» in Intangible Heritage edited by Laurajana Smith and Natsuko Akagawa (Routledge; Abingdon- London, 2009), 13-44.

Boukhari, Sophie. «Beyond the monuments, a living heritage,» UNESCO Sources no. 80 (1996), http://unesdoc.unesco. org/images/0010/001033/103365e.pdf

Bouchenaki, Mounir. «The Interdependency of the Tangible and Intangible Cultural Heritage [Conference Paper],» ICOMOS $14^{\text {th }}$ General Assembly Symposium: ‘ Place, Memory, Meaning: Preserving Intangible Values in Monuments and Sites〉, (27-31 Oct 2003) Victoria Falls, Zimbabwe; 1-5.

Buonaventura, Wendy. Serpent of the Nile: Woman and Dance in the Arab World, (Northampton, 2010).

The Center for Documentation of Cultural and Natural Heritage (CultNat), accessed March 5, 2018: http://www.cultnat. org/

Decker, Wolfgang.»Sports,» The Oxford Encyclopedia of Ancient Egypt- OEAE III (2001); 310 - 314.

Egypt>s Constitution 2014, Constitute Project, translated by International IDEA>s Constitution Net, (17 Jan 2018). https:// www.constituteproject.org/constitution/Egypt_2014.pdf

Egyptian Archives of Folk Life and Folk Traditions. «Folk Traditions». Accessed January 25, 2018.

http://nfa-eg.org/En/egypt_folk_dances/egypt_folk_Definition.aspx?SecID=7

Egyptian Society for Folk Traditions (ESFT). «Report on Traditional Crafts for IMC of the Ministry of Industry.» Accessed March 10, 2018.

http://www.esft.info/en/Projects/Default?id=15.

The Egyptian National Commission for Education Culture and Science. accessed February 22, 2018. http://www.egnatcom. org.eg/ich/en.

«Tally: The Art of Tally,» Egyptian Society for Folk Traditions (ESFT), accessed March 10, 2018,

http://esft.info/en/Projects/Default?id=10.

ESFT and UNESCO, Research Project of Safeguarding Egyptian Traditional Festivals: Collecting \& Documenting Egypt 2008,(Egypt, 2008), http://esft.info/Books/Festivals.pdf.

Emerson, Heather.» Belly Dance,» Hobby Profile: Belly Dance 1. Hobbies \& Crafts Reference Center, EBSCO host (2013); 1-7. library.cityoftyler.org.

Ethnologue. «Languages of the World: Egypt profile.» Accessed March 3, 2018.

https://www.ethnologue.com/country/EG. 
Harris, B. Joyce. African and African-American Traditions in Language Arts, Portland Public Schools Geocultural Baseline Essay Series, (n.d.).

http://www.pps.k12.or.us/depts-c/mc-me/be-af-la.pdf.

ICOM. «Seoul 2004, $21^{\text {st }}$ General Assembly of ICOM.» (Seoul, Korea, Friday 8 October 2004), Accessed February 1, 2018. http://icom.museum/the-governance/general-assembly/resolutions-adopted-by-icoms-general-assemblies-1946to-date/seoul-2004/.

ICOM. «Development of the Museum Definition according to ICOM statutes (2007-1946).» Accessed February $15,2018$. http://archives.icom.museum/hist_def_eng.html.

Ions, Veronica. Library of the Worldss Myths and legends: Egyptian Mythology, (New York, 1982).

Kirshenblatt-Gimblett, Barbara. «Intangible Heritage as Metacultural Production,» Museum International, 56 no. 1-2 (204): 52-65.

Kent, C. Sahra. «The Different Dances of Egypt,» Journey through Egypt, Posted on January 16 ${ }^{\text {th }} 2014$ (Dance Style), http: / / journeythroughegypt.com/the-different-dances-of-egypt/.

Kurin, Richard. «Museums and Intangible Heritage: Culture Dead or Alive?,» ICOM News 4 (2004); 7-9, http://icom. museum/fileadmin/user_upload/pdf/ICOM_News/2004-4/ENG/p7_2004-4.pdf.

Manniche, Lise. Music and Musicians in Ancient Egypt, (London, 1991).

Ministry of Planning, Monitoring and Administrative Reform. Sustainable Development Strategy. Egypt's Vision 2030, (Cairo 2015). Accessed August 20, 2017.

http://www.mfa.gov.eg/SiteCollectionDocuments/SDS2030_English.pdf.

Morsi, Ahmed. «Research and Preservation projects on Intangible Heritage,» Museum International 225-226, Heritage Landscape of Egypt (UNESCO, 2005); 61-66,

http://unesdoc.unesco.org/images/0014/001409/140905e.pdf.

Nielsen, K. Jane. «Transformations in the Postmodern Museum,» Museological Review 18, University of Leicester (2014); 22-29.

Pahwa, Sonali and Winegar, Jessica. «Culture, State and Revolution,» Middle East Research and Information Project- MERIP 42 ( 263), accessed March 21, 2018. https://www.merip.org/mer/mer263/culture-state-revolution.

Stefano, L. Michelle. «Safeguarding intangible heritage: five key obstacles facing museums of the North East of England,» International Journal of Intangible Heritage, no. 04 (2009); 112- 123,

https://www.academia.edu/234065/Safeguarding_Intangible_Heritage_Five_Limitations_Facing_Museums_of_ North_East_England.

Supreme Council of Antiquities, Law No. 117 of 1983, as amended by Law N. 3 of 2010 (14 February, 2010), promulgating the Antiquities> Protection Law (6 August 1983), 1-39.

Tobin, A. Vincent. «Mythological Texts,» The Oxford Encyclopedia of Ancient Egypt- OEAE II, (2002); 459-464.

UNESCO and WIPO, Model Provisions for National Laws on the Protection of Expressions of Folklore against Illicit Exploitation and Other Prejudicial Actions, (Paris, (1985), Section 2. http://www.wipo.int/export/sites/www/tk/en/ folklore/1982-folklore-model-provisions.pdf

UNESCO, Recommendation on the Safeguarding of Traditional Culture and Folklore, adopted by the General Conference at its twenty-fifth session ( Paris, 15 November 1989), http://unesdoc.unesco.org/images/0009/000926/092693mb. pdf.

UNESCO, Report on the Preliminary Study on the Advisability of Regulating Internationally, through a New Standard-Setting Instrument, The Protection of Traditional Culture and Folklore (Paris, 16 May 2001), http://unesdoc.unesco.org/ images/0012/001234/123437e.pdf.

UNESCO, Convention for the Safeguarding of the Intangible Cultural Heritage, (Paris, 17 October 2003), http://unesdoc. unesco.org/images/0013/001325/132540e.pdf.

UNESCO, UNESCO Convention on the Protection and Promotion of the Diversity of Cultural Expressions, (Paris, 2005) Art.4 (3).

UNESCO, Masterpieces of the Oral and Intangible Heritage of Humanity, Proclamations 2001, 2003, and 2005 (2006), 6. http://unesdoc.unesco.org/images/0014/001473/147344E.pdf.

UNESCO Egypt. Country Nomination File no. 01189 for inscription in 2016 on the Representative List of the Intangible Cultural Heritage of Humanity, intergovernmental Committee for the Safeguarding the Intangible Cultural Heritage, eleventh session ( Addis-Ababa, Ethiopia, 2016), https://ich.unesco.org/en/RL/tahteeb-stick-game-01189.

UNESCO Egypt, Periodic Report on the Convention for the Safeguarding of the Intangible Cultural Heritage: Intergovernmental Committee for the Safeguarding of the Intangible Cultural Heritage- Seventh Session, Paris- Periodic Report No. 00788/ 
Egypt. https://ich.unesco.org/en/state/egypt-EG?info=periodic-reporting\#pr-2012-2012.

UNESCO, «Egypt and the 2003 Convention,». Accessed January 12, 2018. https://ich.unesco.org/en/state/egypt-EG. UNESCO Egypt, Working Paper Submitted by the Egyptian Delegation to the Conference Meeting of Open Membership Team of Governmental Experts Concerning Protection from Illicit Trading in Cultural Property, (Vienna from 24 to 26 November, 2009). Accessed January 1, 2018. http://www.unodc.org/documents/treaties/organized_crime/Egypt.pdf.

UNESCO, What is Intangible Cultural Heritage?, (n.d.) 6, https://ich.unesco.org/doc/src/01851-EN.pdf.

Winegar, Jessica . «Culture is the Solution: the Civilizing Mission of Egypt s Culture Palaces,» Romes 43 (2), (2009); $189-19$. WIPO, Glossary of Key Terms related to Intellectual Property and Generic Resources, Traditional Knowledge and Traditional Cultural Expressions, in: Intergovernmental Committee on Intellectual Property and Genetic Resources, Traditional Knowledge and Folklore, Twenty - Second Session, (Geneva, July 9-13, 2012), http://www.wipo.int/edocs/mdocs/tk/ en/wipo_grtkf_ic_22/wipo_grtkf_ic_22_inf_8.pdf.

World Atlas, «Languages Spoken in Egypt.» Accessed March 3, 2018. https://www.worldatlas.com/articles/languagesspoken-in-egypt.html

Zingari. L. Valentina, Rosario Perricone and Pietro Clemente (Simbdea). Position Paper: International Conference and Expert Meeting on Museums, Intangible Cultural Heritage and Participation (27-28 February, 2018, Palermo). Accessed April 10, 2018.

https://www.ichandmuseums.eu/en/events/detail/expert-meeting-intangible-cultural-heritage-museums-andparticipation 